\title{
HAK WARIS BAGI ANAK HASIL KLONING PERSPEKTF HUKUM ISLAM
}

\author{
Oleh : Maimun*
}

\begin{abstract}
ABSTRAK
Kloning menggunakan sel telur dan sel selain sperma. Babkan dikatakean, secara teoritis, melalui teknik kloning kelahiran seorang bayi tidak lagi memerlukan sperma ayah. Babkan seorang perempuan dapat mempunyai anak tanpa melalui ikatan perkawinan. Demikian juga seorang lelaki apabila ingin punya anak tidak perlu beristri. Cukup banya memesan sel telur pada suatu firma, memberikan selnya dari salah satu organ tububnya dan kemudian menitipkan calon anaknya pada rabim seorang wanita yang bisa jadi telah disediakan oleh firma tersebut, Bahwa status anak hasil kloning juga termasuk. anak yang dibasilkan bukan dari proses perkawinan yang sab dan tanpa adanya bubungan suami istri karena bisa jadi seseorang perempuan dan laki-laki bisa ada penerus genetiknya tanpa harus melalui proses perkawinan terlebih dabulu. Dan dalam permasalaban kewarisan tidak termasuk kedalam sebab-sebab menerima warisan terhadap anak hasil kloning tersebut, karena anak basil kloning; tidak adanya hubungan kerabat antara keduanya; tidak adanya bubungan suami istri antara keduanya (karena proses kloning tanpa bubungan suami istri).
\end{abstract}

\section{Kata Kunci : Waris; Kloning; Perspektif dan Hukum Islam.}

\section{PENDAHULUAN}

Dengan semakin berkembangnya kemajuan ilmu pengetahuan terutama dalam bidang kedokteran dan perkembangan masyarakat yang semakin dinamis memunculkan ide untuk menciptakan kelahiran tanpa melalui proses alami, yakni melalui proses kloning, yang bertujuan membantu pasangan suami-isteri yang mengalami kemandulan untuk mendapatkan keturunan. Tapi kini program kloning tidak lagi hanya bertujuan untuk membantu pasangan suami-isteri untuk mendapatkan

* Penulis Adalah Dosen Institut Agama Islam Al-Aziziyah Samalanga, Email: maimun@yahoo.co.id 
keturunan, tetapi juga bertujuan untuk mendapatkan "manusia super" sesuai keinginan manusia yang "menciptakannya". yang dapat membuat manusia unggul seperti yang diinginkan. Hebatnya lagi, tinggal mengambil DNA dari manusia yang ingin di kloning, dan yang lebih fenomenal, wanita bisa mempunyai anak tanpa membutuhkan pria. Jika ingin mempunyai anak secerdas Einstein, maka tinggal mengambil DNA dari Einstein tersebut.

Pada saat ini kloning tidak mempergunakan sel sperma lagi seperti yang dilakukan dr. Jerry Hall pada pertama kali ditemukannya kloning embrio. Tapi kloning menggunakan sel telur dan sel selain sperma. Bahkan dikatakan, secara teoritis, melalui teknik kloning kelahiran seorang bayi tidak lagi memerlukan sperma ayah. Bahkan seorang perempuan dapat mempunyai anak tanpa melalui ikatan perkawinan. Demikian juga seorang lelaki apabila ingin punya anak tidak perlu beristri. Cukup hanya memesan sel telur pada suatu firma, memberikan selnya dari salah satu organ tubuhnya dan kemudian menitipkan calon anaknya pada rahim seorang wanita yang bisa jadi telah disediakan oleh firma tersebut (Partaolan Daulay, 2005:43).

Namun permasalahannya dalam terminologi fiqh yang menjadi permasalahannya adalah bagaimana nanti status hukum dan hak waris anak yang dilahirkan dari proses kloning embrio manusia tersebut? Disiplin ilmu banyak yang mengomentari fenomena ini, karena sebelumnya belum pernah terjadi dan belum pernah ada, baik dalam alQur'an maupun dalam Undang-undang. Karena itu penting bagi penyusun untuk menganalisis konsep hukum kewarisan dalam Islam dengan. Kajian ini merupakan kajian hukum maka pendekatan yang digunakan dalam penelitian ini adalah pendekatan yuridis, yakni mengkaji dan menelaah sumber-sumber hukum yang ada, yaitu hukum Islam.

\section{HASIL DAN PEMBAHASAN}

\section{A. Kloning Embrio Manusia}

Rekayasa Genetika, juga dinamakan Pencangkokan Gen atau DNA Rekombinan, dinyatakan sebagai kemajuan yang paling mengagumkan semenjak manusia berhasil memisahkan atom. Penelitian tentang rekayasa genetika sesungguhnya telah dimulai pada awal tahun 1950-an, namun teka-teki ini baru dapat memperoleh hasil 20 tahun kemudian (Yatim, 1982:30)

Mula-mula rekayasa genetika dianggap sebagai suatu impian masa depan dalam ceritera ilmiah. Tetapi kini kemampuan untuk mencangkokkan bahan genetik dan membongkar kembali informasi keturunan, memberikan hasil sangat nyata dan telah terbukti sangat 
bermanfaat. Seperti diketahui, bahan genetik DNA (asam deoksiribonukleat) yang mengandung informasi keturunan, dan dimiliki oleh kebanyakan makhluk hidup itu berupa pita ganda yang saling berpilin membentuk spiral ("double helix") (Istyhafid: 2010).

Pada masalah penggunaan DNA pada proses kloning embrio, merupakan masalah yang rumit, karena DNA bisa diambil dari siapa saja yang diinginkan. Yang bisa membuat permasalahan bagi silsilah keturunannya kelak. Anak siapa? Keturunan siapa? hingga mempersulit dalam pembuatan akte kelahiran, hak waris. Juga dari permasalahan izin penggunaan DNA tersebut, apakah dapat dengan seenaknya mengambil DNA orang lain tanpa seizin orang yang mempunyai DNA tersebut.

Pada tataran moral, etika dan agama masih menjadi kontroversi, pada domain hukum sampai saat ini belum ada hukum yang menangani Kloning Embrio manusia di Indonesia secara khusus yang juga akan berimplikasi terhadap hak waris terhadap anak hasil kloning tersebut. $\mathrm{Hal}$ itu seharusnya sudah dipikirkan, sebab tidak menutup kemungkinan kasus adanya kloning embrio manusia ini akan ada di Indonesia. mengingat teknologi membelah embrio itu tidak tergolong sulit atau mahal.

\section{B. Hukum Kewarisan Islam}

Hukum kewarisan sering dikenal dengan istilah faraidh. Hal ini karena dalam Islam, bagian-bagian warisan yang menjadi hak ahli waris telah ditentukan dalam Alquran. Hukum kewarisan dalam Islam mendapat perhatian besar, karena pembagian warisan sering menimbulkan akibatakibat yang tidak menguntungkan (Ahmad Rofik, 1995: 355).

Secara etimologis, faraidh diambil dari kata fardh yang berarti taqdir "ketentuan". Dalam istilah syara' bahwa kata fardh adalah bagian yang telah ditentukan bagi ahli waris (Sayyid Sabiq, 2006:479).

1. Pengertian Waris

Hukum kewarisan menurut figh mawaris adalah fiqih yang berkaitan dengan pembagian harta warisan, mengetahui perhitungan agar sampai kepada mengetahui bagian harta warisan dan bagian-bagian yang wajib diterima dari harta peninggalan untuk setiap yang berhak menerimanya.

Pengertian hukum kewarisan menurut Pasal 171 huruf a Kompilasi Hukum Islam adalah hukum yang mengatur tentang pemindahan hak pemilikan harta peninggalan (tirkah) pewaris, menentukan siapa-siapa yang berhak menjadi ahli waris dan berapa bagiannya masing-masing. Dalam konteks yang lebih umum, warisan dapat diartikan sebagai perpindahan hak kebendaan dari orang yang meninggal dunia kepada ahli warisnya yang masih hidup (Ahmad Rofiq, 2002: 4). 
Mewaris berarti menggantikan tempat dari seseorang yang meninggal dalam hubungan hukum harta kekayaannya. Hubunganhubungan hukum yang lain, misalnya hubungan hukum dalam hukum keluarga (R Soetojo, 2000: 3). Dalam redaksi yang lain, Hasby AshShiddieqy mengemukakan, hukum kewarisan adalah hukum yang mengatur siapa-siapa orang yang mewarisi dan tidak mewarisi, bagian penerimaan setiap ahli waris dan cara-cara pembagiannya. Wirjono Prodjodikoro menjelaskan, warisan adalah soal apa dan bagaimana berbagai hak-hak dan kewajiban-kewajiban tentang kekayaan seseorang pada waktu ia meninggal akan beralih kepada orang lain yang masih hidup (Ahmad Rofiq, 2002: 4).

2. Dasar Hukum Kewarisan

1) Adapun yang menjadi dasar pelaksanaan pembagian harta warisan dalam hukum Islam adalah berpedoman pada ayat-ayat Alquran berikut ini, yaitu :
a) Surat An-Nisa' ayat 7
b) Surat An-nisa' ayat 8
c) Surat An-Nisa' ayat 11
d) Surat An-Nisa' ayat 12
e) Surat An-Nisa' ayat 33
f) Surat An-Nisa' ayat 176
g) Surat Al-Baqarah ayat 180
h) Surat Al-Baqarah ayat 240
i) Surat Al-Azhab ayat 4

2) Pedoman pelaksanaan hukum waris Islam menurut Ijtihad adalah : Masalah-masalah yang menyangkut warisan ada yang sudah dijelaskan permasalahannya dalam Al-Qur'an atau sunnab dengan keterangan yang kongkret, sehingga tidak timbul macam-macam interpretasi, bahkan mencapai ijma' (konsensus) di kalangan ulama dan umat Islam. Selain dari itu masih banyak masalah warisan yang dipersoalkan atau diperselisihkan (Muhammad Jawad, 2000: 535)

3) Dan dasar hukum pelaksanaan pembagian warisan menurut Kompilasi Hukum Islam (KHI), yaitu terdapat dalam Pasal 171193 KHI.

3. Sebab-Sebab Menerima Warisan

1) Adanya Hubungan Kerabat Antara Keduanya.

Sebab pertama seorang berhak mendapat harta waris dari si mayit, adalah adanya hubungan kerabat antara si mayit dengan orang tersebut, maka ayah dan ibu berhak mendapatkan harta waris jika anaknya meninggal. Karena mereka berdua adalah kerabatnya, yaitu orang tuanya, begitu pula sebaliknya sang anak berhak 
mewarisi harta orang tuanya karena dia adalah anaknya, dan begitu seterusnya. Kesimpulannya bahwa kerabat adalah ayah, ibu dan siapapun yang ada hubungan dengan mayit lewat keduanya seperti saudara, paman, dan lain-lain. Begitu pula anak laki-laki atau perempuan dan siapapun yang ada hubungan kerabat dengan mayit lewat mereka. Seperti cucu, cicit dari anak laki-laki, dan lainlain.

2) Adanya Hubungan Suami Istri Antara Keduanya.

Sebab yang kedua seorang mendapat harta waris dari si mayit adalah adanya hubungan suami istri antara keduanya, baik yang meninggal sang suami maupun sang istri. Asalkan akad nikahnya sesuai dengan prosedur agama dan dianggap sah walaupun keduanya tidak atau belum melakukan hubungan intim, maka keduanya saling mewarisi. Lain halnya jika akad nikahnya dianggap tidak sah oleh agama misalnya perkawinan tanpa wali, tanpa saksi atau kawin mut'ah. Maka keduanya tidak saling mewarisi.

Jika tercerai dengan talak raj'i (mentalak istri dengan talak satu atau dua) lalu suami meninggal dunia sebelum sang istri selesai dari iddahnya, maka istri tersebut berhak mendapat harta waris dari mantan suaminya. Dan jika suaminya meninggal setelah si istri selesai melaksanakan iddah atau sang istri ditalak dengan talak bain sughroh maupun kubro (talak satu atau dua tapi selesai iddahnya begitu pula jika dicerai sebelum disetubuhi, atau diceraikan dengan cara talak khulu' (dengan imbalan), maka istri tersebut tidak berhak mendapatkan harta waris dari mantan suaminya

3) Hubungan Wala'

Sebab yang ketiga seseorang berhak mendapatkan harta waris adalah adanya hubungan wala' antara keduanya. Yang dimaksudkan dengan wala' di sini adalah seseorang berhak mendapatkan asobahnya si mayit karena dia adalah bekas tuan dari si mayit yang pernah dia merdekakan. Maka jika ada bekas hamba sahaya meninggal dunia tanpa meninggalkan seorang ahli warispun, atau meninggalkan ahli waris akan tetapi termasuk ahli furud (ahli waris yang berhak mendapatkan harta waris secara fard) maka agama memutuskan semua harta warisnya atau sisa pengambilan ahli furud diberikan kepada mantan tuannya tersebut sebagai balas jasa atas kebaikannya terhadap bekas budaknya itu dengan memerdekakannya.

4. Pengertian Pewaris

Pewaris adalah orang yang meninggal dunia, baik laki-laki maupun perempuan yang meninggalkan sejumlah harta benda maupun hak-hak 
yang diperoleh selama hidupnya, baik dengan surat wasiat maupun tanpa surat wasiat.

5. Pengertian Ahli Waris

Ahli waris adalah orang-orang yang berhak menerima harta peninggalan (mewarisi) orang yang meninggal, baik karena hubungan keluarga, pernikahan, maupun karena memerdekakan hamba sahaya (wala).

\section{Kewarisan Anak Kloning (Luar Nikah) Menurut Islam}

Islam telah mengatur konsep kewarisan yang ideal untuk diikuti. Ketentuan-ketentuan mengenai kewarisan termuat dalam Alquran dan Hadis yang ketentuan itu bersifat qath'i atau pasti sebagaimana telah terjadi ijma' di kalangan yuris Islam. Walaupun demikian, tidak menutup kemungkinan adanya ketentuan lain mengenai pembagian harta warisan, yaitu asas kekeluargaan.

Dalam hukum waris Islam, telah diatur pula ketentuan mengenai orang-orang yang mempunyai hak ataupun tidak dalam menerima harta warisan. Ketentuan tersebut dilandasi dengan suatu sebab. Adapun sebab seseorang mendapat warisan menjadi unsur penting dalam pembahasan ilmu mawaris, karena dari sebab itu peralihan harta warisan menjadi sah. Ada tiga sebab pemenuhan hak seseorang terhadap harta warisan, yaitu adanya hubungan nashab (keturunan), mushaharab (perkawinan), dan wala' (memerdekakan budak).

1. Pengertian Anak Luar Nikah

Dalam literatur fiqh klasik, istilah "anak luar nikah" hampir atau bahkan tidak dijumpai, karena istilah ini sering digunakan dalam konteks ke Indonesiaan. Walaupun demikian, dalam peraturan perundangundangan Indonesia, khususnya dalam Undang-Undang Nomor 1 tahun 1974 tentang Perkawinan dan Kompilasi Hukum Islam (KHI) disebutkan dengan nama "anak di luar perkawinan", bukan "anak luar nikah". Hal ini dimaksudkan mungkin karena kata nikah diartikan sama dengan istilah kawin, sehingga penamaan anak itupun selalu diikuti dengan istilah "luar nikah" atau "luar kawin". Dalam fiqh Islam, istilah tersebut sering disebut sebagai anak zina, karena anak tersebut dinisbatkan kepada perbuatan kedua orang tuanya, yaitu berzina (Tim Penulis UIN Syaif Hidayatullah, 1992: 119).

Dalam hukum Islam, seseorang dapat dikatakan anak luar nikah atau anak luar kawin apabila proses yang mengakibatkan anak tersebut menjadi ada itu dari suatu perbuatan yang dilarang oleh hukum Islam, anak kloning merupakan proses terjadinya tanpa adanya hubungan pernikahan terlebih dahulu antara laki-laki dengan perempuan, hanya 
dengan menggunakan DNA Laki-laki dengan DNA perempuan, sehingga mengakibatkan status anak kloning tersebut tidak ada kejelasan siapa Bapak dan siapa Ibunya, sehingga dalam ketentuan hukum Islam menentukan bahwa anak tersebut tidak mempunyai hubungan nasab dengan bapaknya ataupun dengan ibunya.

Mengenai defenisi anak luar nikah, menurut Amir Syarifuddin, beliau mengistilahkannya dengan anak zina (Amir Syarifuddin, 2008: 148). Menurutnya, Anak zina adalah anak yang dilahirkan dari suatu perbuatan zina, yaitu hubungan kelamin antara laki-laki dengan perempuan yang tidak terikat dalam nikah yang sah meskipun ia lahir dalam suatu perkawinan yang sah dengan laki-laki yang melakukan zina atau dengan laki-laki lain. Sedangkan menurut Syaikh Kamil Muhammad Uwaidah, Anak zina adalah anak yang dilahirkan ibunya dari hasil hubungan badan di luar nikah yang sah menurut Islam Jika dilihat melalui perspektif hukum adat, anak zina sering disebut dengan anak haram atau anak haram jadah, yaitu anak yang lahir diluar perkawinan yang sah. Anak yang dilahirkan di luar perkawinan tersebut selanjutnya disebut dengan anak haram, karena ia dilahirkan dari perbuatan yang diharamkan yaitu zina. Kemudian dalam ensiklopedi Islam disebutkan bahwa anak haram lazim disebut dengan julukan anak zina yaitu anak yang dilahirkan di luar perikahan yang dipandang sah menurut syari'at. Atau dengan kalimat lain, anak zina adalah anak yang dilahirkan oleh seorang wanita sebagai akibat (hasil) dari hubungan senggamanya dengan laki-laki yang bukan saminya (Tim Penulis UIN Syaif Hidayatullah, 1992: 119).

Jika dilihat dari peraturan perundang-undangan, tidak disebutkan mengenai pengertian anak luar nikah atau anak luar kawin secara eksplisit, tetapi pengertian tersebut dapat dipahami dari beberapa bunyi pasal, diantaranya dalam Pasal 99 Kompilasi Hukum Islam disebutkan bahwa, anak yang sah adalah:

a. anak yang dilahirkan dalam atau akibat perkawinan yang sah,

b. hasil perbuatan suami isteri yang sah di luar rahim dan dilahirkan oleh isteri tersebut. Kemudian dalam pasal 100 Kompilasi Hukum Islam disebutkan, bahwa "anak yang lahir di luar perkawinan hanya mempunyai hubungan nasab dengan ibunya dan keluarga ibunya".

Dari bunyi beberapa pasal di atas dapat dipahami bahwa seorang anak dapat dikatakan sab apabila kelabirannya tersebut termasuk dalam perkawinan yang sah dan sebagai akibat dari perkawinan yang sah, sebaliknya anak luar nikah atau anake luar kawin adalah seorang anak yang dilabirkan di luar perkawinan dan akibat dari bubungan yang tidak sah. Pengertian ini dapat juga dipahami dari bunyi Pasal 42 Undang-Undang Nomor 1 Tahun 1974 
tentang Perkawinan, disebutkan, bahwa "anak yang sab adalab anak yang dilabirkan dalam atau sebagai akibat perkawinan yang sab". Selain itu terdapat pula keterangan Pasal 43 ayat 1, bahwa "anak yang dilahirkan di luar perkawinan hanya mempunyai hubungan perdata dengan ibunya dan keluarga ibunya".

Berdasarkan penjelasan di atas bisa disimpulka bahwa status anak hasil kloning juga termasuk anak yang dihasilkan bukan dari proses perkawinan yang sah dan tanpa adanya hubungan suami istri karena bisa jadi seseorang perempuan dan laki-laki bisa ada penerus genetiknya tanpa harus melalui proses perkawinan terlebih dahulu. Dan dalam permasalahan kewarisan tidak termasuk kedalam sebab-sebab menerima warisan terhadap anak hasil kloning tersebut, karena anak hasil kloning; tidak adanya hubungan kerabat antara keduanya; tidak adanya hubungan suami istri antara keduanya (karena proses kloning tanpa hubungan suami istri); dan tidak adanya hubungan wala'.

2. Status Nasab Anak kloning Menurut Islam

Nasab menurut bahasa yaitu keturunan, silsilah, atau asal usul. Sedangkan menurut istilah, nasab adalah penggunaan terhadap asal-usul seseorang kepada orang lain yang secara hukum dikaitkan dengan adanya hak dan kewajiban di dalamnya. Terdapat pengaruh yang sangat besar terhadap ada tidaknya suatu hubungan perkawinan. Umat Islam secara keseluruhan sepakat bahwa terdapat konsekuensi hukum yang timbul terhadap hubungan yang dilandasi dengan perkawinan yang sah, tentu dalam konteks ini dimaksudkan adalah adanya hubungan nasab antara anak dengan orang tuanya. Sebaliknya, jika anak tersebut dihasilkan dari hubungan yang tidak diakui secara syara' hubungan yang tidak sah atau di luar perkawinan yang sah, maka akan berkonsekuensi tidak diakuinya nasab anak kepada ayahnya. Dalam hal ini, anak yang disebut terakhir tadi disamakan dengan status anak mula'anah (ibnu mula'anab).

Nasab adalah salah satu pondasi kuat yang menopang berdirinya sebuah keluarga, karena nasab mengikat antar anggota keluarga dengan pertalian darah. Dalam hal ini, anak adalah bagian dari pada ayah. Begitu pentingnya sebuah nasab, maka nasab merupakan salah satu dari lima maqashid syari'ah. Wahbah Zuhaily menyebutkan bahwa nasab seorang anak terhadap ibunya tetap bisa diakui dari setiap sisi kelahiran, baik yang syar'i maupun tidak. Adapun nasab seorang anak dengan ayahnya hanya bisa diakui dengan adanya nikah yang shabih atau fasid, atau wathi' syubhat (persetubuhan yang samar status hukumnya), atau pengakuan nasab itu sendiri, di dalam Islam sering disebut sebagai istilhaq (pengakuat terhadap seorang anak). Kemudian beliau menambahkan bahwa Islam telah menghapus hukum adat yang berlaku pada zaman jahiliah terhadap nasab anak zina. 
Sebagaimana yang dituturkan oleh Wahbah Zuhaily dalam tulisannya bahwa terdapat tiga cara dalam menentukan hubungan nasab seorang anak, yaitu; pertama, Pernikahan yang sah. Bahwa Tidak dapat dipungkiri suatu hubungan perkawinan merupakan awal dari adanya hubungan nasab bagi anak keturunan. Semua imam mazhab sepakat akan hal ini dan tidak ada pengecualian.

Kedua, dengan cara pengakuan garis nasab atau keturunan (itsbat nasab bil iqrar). Pengakuan garis nasab atau keturunan dalam istilah fiqh disebut dengan istilhaq. Menurut sebagian ahli hukum Islam Indonesia, seperti Abdul Manan menyatakan anak zina yang dilahirkan di luar pernikahan yang sah akibat hubungan ghairu syari' tetap bisa diakui dengan jalan istilhaq apabila tidak terpenuhinya secara zahir bahwa hubungan mereka tidak sah (berzina), seperti tidak terpenuhinya empat orang saksi yang adil.

Ketiga, dengan cara pembuktian. Dalam hukum Islam juga terdapat aturan hukum tentang nasab seorang anak dengan ayahnya dengan cara pembuktian. Cara ini juga sering disebut dengan mubaiyyinah (perbandingan), yaitu dengan cara pembuktian berdasaran bukti yang sah bahwa seorang anak betul-betul senasab dengan orang tuanya ((Tim Penulis UIN Syaif Hidayatullah, 1992: 37). Misalnya dengan melihat kemiripan dari orang tua dengan anaknya yang didukung dengan adanya pengakuan dari masyarakat bahwa mereka mempunyai hubungan nasab.

Asal usul anak merupakan dasar untuk menunjukkan adanya hubungan nasab dengan ayahnya. Karena para ulama sepakat bahwa anak hasil zina dan li'an hanya memiliki hubungan nasab dengan ibu dan keluarga ibunya. Majelis Ulama Indonesia (MUI) juga mengeluarkan fatwa Nomor 11 Tahun 2012 Tentang Kedudukan Anak Hasil Zina Dan Perlakuan Terhadapnya. Hasil dari fatwa tersebut secara umum menyatakan atas pertimbangan hukum yang ada baik dari Alquran, Hadis serta pendapat mayoritas fuqaha bahwa anak yang yang lahir luar nikah tidak memiliki hubungan nasab dengan ayah dan keluarga ayahnya.

Dari beberapa pendapat serta argumen hukum di atas, dapat dipahami dalam bentuk klausul bahwa nasab menjadi unsur terpenting dalam sebuah keluarga. Dalam kasus ini, anak yang lahir di luar perkawinan atau anak luar nikah tidak memiliki hubungan nasab dengan ayah dan keluarga ayahnya dan statusnya disamakan dengan anak li'an. Kesimpulan hukum seperti ini bisa dijadikan pijakan dengan melihat pendapat yang mu'tabar, selain adanya ijma' di kalangan ulama yang menentukan bahwa anak tesebut tidak memiliki hubungan nasab dengan ayahnya. Jika diruntut tentang hubungan antara perkawinan dengan nasab, bahwa perkawinan merupakan awal dari adanya hubungan nasab atau 
keturunan yang sah. Terhadap hubungan perkawinan yang sah, maka selanjutnya akan berinplikasi pada sahnya hubungan nasab. Dari hubungan kausalitas tersebut akan berlaku hukum yang berupa hubungan hak dan kewajiban dalam lingkup keperdataan.

3. Pendapat Ulama Tentang Hak Waris Anak Luar Nikah

Dalam produk figh klasik, jumbur ulama sepakat bahwa anak luar nikah tidak mendapat hak waris dari ayahnya dan sebaliknya, sebagaimana disebutkan oleh Imam Syafi'i yang dikutip oleh Wahbah Zuhaily bahwa status anak zina disamakan dengan anak mula'anah dengan ketentuan bahwa anak tersebut terputus hubungan saling mewarisi dengan ayah dan keluarga ayahnya, karena tidak adanya status nasab yang sah di antara mereka. Dalil hukum yang dapat dikemukakan ialah dari beberapa Hadis Rasul yang artinya:

"Telah menceritakan kepada kami Ibrabim bin Musa Ar Raæi, telah menceritakan kepada kami Mubammad bin Harb, telab menceritakan kepadaku Umar bin Ru'bah At Taghlibi, dari Abdul Wabid bin Abdullah An Nashri, dari Watsilah bin Al Asqa' dari Nabi shallallabu 'alaibi wasallam beliau bersabda: "Seorang wanita menjaga tiga orang yang mewarisi; budak yang ia bebaskan, anak. temuannya, dan anaknya yang karenanya ia melakukan li'an."(HR. Abu Daud).

Kemudian Hadis yang diriwayatkan oleh Tirmizi, yaitu:

"Telah menceritakan kepada kami Qutaibab; telah menceritakan kepada kami Ibnu Labi'ab dari 'Amr bin Syu'aib dari bapaknya dari kakeknya bahwasanya Rasulullah shallallabu 'alaibi wasallam bersabda: "Siapa saja lelaki yang berzina dengan wanita merdeka maupun budak wanita, maka anaknya ialah anak hasil zina. Dia tidak mewarisi juga tidak diwarisi." (HR. Tirmidzi)

Dari dua Hadis tersebut menurut Wahbah Zuhaily cukup untuk membuat sebuah kesimpulan bahwa anak di luar nikah tidak mewarisi harta ayahnya dan ayahnya tidak memiliki hak waris atas hartanya. Dalam hukum Islam telah ditentukan pula bahwa adanya suatu hak nashab bagi seseorang harus dilandasi dengan adanya sebab yaitu perkawinan yang sah. Selanjutnya sebab perkawinan yang menjadi salah satu syarat terhadap pemenuhan hak nashab akan berujung pada pemenuhan hak waris mewarisi. Kesimpulan hukum seperti ini digali melalui beberapa bunyi Hadis di atas serta firman Allah surat an-Nisa' ayat 11, 12 dan 176 tentang warisan. Dalam surat an-Nisa' ayat 11 disebutkan yang artinya: 


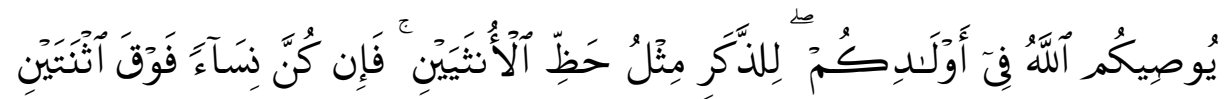

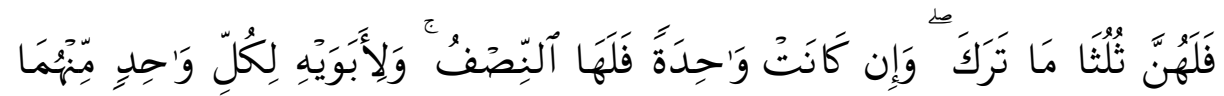

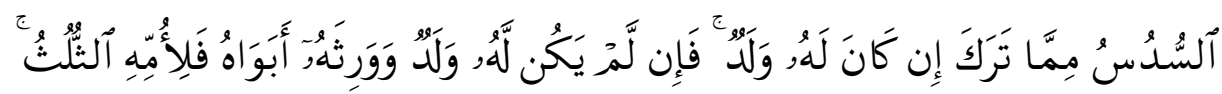

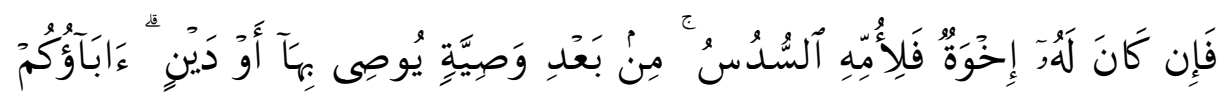

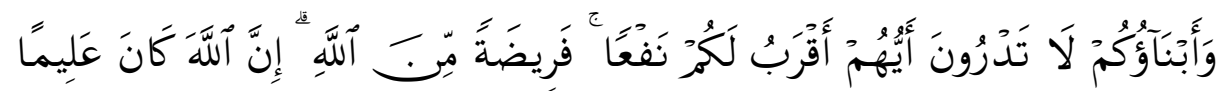

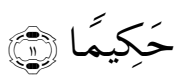

Artinya: Allah mensyari'atkan bagimu tentang (pembagian pusaka untuk) anak-anakmu. Yaitu : bahagian seorang anak lelaki sama dengan bagahian dua orang anak perempuan; dan jika anak itu semuanya perempuan lebih dari dua, Maka bagi mereka dua pertiga dari harta yang ditinggalkan; jika anak perempuan itu seorang saja, Maka ia memperoleh separo harta. dan untuk dua orang ibu-bapa, bagi masing-masingnya seperenam dari harta yang ditinggalkan, jike yang meninggal itu mempunyai anak; jika orang yang meninggal tidak mempunyai anak dan ia diwarisi oleb ibu-bapanya (saja), Maka ibunya mendapat sepertiga; jika yang meninggal itu mempunyai beberapa saudara, Maka ibunya mendapat seperenam. (Pembagian-pembagian tersebut di atas) sesudah dipenubi wasiat yang ia buat atau (dan) sesudab dibayar butangnya. (Tentang) orang tuamu dan anak-anakmu, kamu tidak mengetahui siapa di antara mereka yang lebih dekat (banyak) manfaatnya bagimu. ini adalah ketetapan dari Allah. Sesunggubnya Allab Maha mengetahui lagi Maha Bijaksana.

Pemahaman dari ayat di atas sebagaimana terlihat dari penjelasan Wahbah Zuhaily bahwa kata "anak-anakmu" merupakan keturunan yang berhak mendapat harta warisan dari ayahnya, karena adanya hubungan darah. Selanjutnya, hubungan darah tersebut akan berlaku atau diakui oleh hukum syara' apabila didahului dengan adanya hubungan perkawinan sah yang melatar belakangi adanya garis keturunan yang sah tersebut. Dalam hal ini, dapat dipahami juga bahwa suatu perbuatan hukum akan mempunyai hubungan kausalitas (hubungan sebab akibat) dengan perbuatan hukum lainnya. 
Menurut pandangan Shaleh Al-Fauzan, penyebab seseorang mendapatkan harta warisan adalah karena hubungan darah dari kedua orang tuanya, adapun dalilnya yaitu dalam Alquran surat Al-Ahzab ayat 6 yang artinya:

"..dan orang-orang yang mempunyai bubungan darah satu sama lain lebib berbak (waris-mewarisi) di dalam kitab Allah.."

Dari ayat di atas beliau berpendapat bahwa suatu hubungan kekerabatan (hubungan darah atau nasab) merupakan faktor yang mempengaruhi seseorang mempunyai hak dan kewajiban, sedangkan kasus anak kloning ini tidak adanya hubungan darah yang sah diakui dalam Islam sehingga berimplikasi terhadap status anak tersebut termasuk dalam hal ini adalah perihal warisan. Hubungan darah yang dimaksud dalam ayat di atas harus dibenarkan menurut hukum, yaitu wajib adanya suatu hubungan akad nikah yang sah. Berawal dari adanya perkawinan yang sah maka terdapat pula hubungan darah yang sah menurut syara'.

Jika beralih ke wilayah hukum Indonesia, para pakar hukum Islam Indonesia juga telah memberikan kontribusi yang cukup besar melalui pendapat-pendapat yang disuguhkan terhadap status waris anak luar nikah (kloning). Di antara pendapat yang dapat dikemukakan yaitu menurut Muhammad Hasbi Ash-Shiddieqy, bahwa apabila seseorang telah terang hubungan darahnya dengan ibu bapaknya, maka dia mewarisi ibu bapaknya dan ibu bapaknya mewarisinya selama tidak ada satu penghalang pusaka dan selama syarat-syarat pusaka telah cukup sempurna. Dalam kasus anak kloning (di luar nikah), maka anak tersebut hanya memiliki hubungan darah dengan pemilik DNA Ibunya saja dan keluarga ibunya dan tidak diakui hubungan darah dengan DNA Laki-laki serta keluarganya.

Jika pendapat dari pakar hukum Indonesia dikaitkan dengan aturan hukum dalam hal ini yaitu peraturan peundang-undangan yang ada di Indonesia agaknya dapat dikatakan sejalan dan mempunyai kesamaan, hal ini mungkin disebabkan karena aturan perundang-undangan yang ada juga merujuk pada pendapat ulama-ulama terdahulu. Dalam buku I Kompilasi Hukum Islam, tepatnya pada Pasal 100 disebutkan bahwa;

"anak yang labir di luar perkawinan banya mempunyai bubungan nasab dengan ibunya dan keluarga ibunya".

Dalam hal ini, sesuai dengan ketentuan dalam buku II KHI, tepatnya pada Pasal 171 huruf c dinyatakan bahwa:

"Abli waris adalah orang yang pada saat meninggal dunia mempunyai bubungan darah atau bubungan perkawinan dengan pewaris, beragama Islam dan tidak terbalang karena bukum untuk menjadi abli waris" (Tim Redaksi Nuansa Aulia, 1992: 52) 
Dari bunyi pasal di atas dapat dipahami bahwa pada pasal 100 menyatakan tentang kedudukan nasab anak luar nikah, sedangkan pada pasal 171 menyatakan tentang kedudukan ahli waris yang menurut hukum mendapatkan hak warisan. oleh karena anak luar nikah tidak memiliki hubungan nasab dengan ayahnya, maka anak tersebut tidak tergolong dalam ahli waris.

\section{Kloning Menurut Al-Qur'an dan Hadis}

Kemajuan di bidang teknologi belakangan ini memang berkembang sangat pesat, banyak penemuan baru tentang biologi molukular, di antaranya yaitu adanya sistem kloning. Sistem kloning itu sendiri merupakan suatu proses menghasilkan individu-individu dari jenis yang sama yang identik secara genetik. Pada hewan atau tumbuhan tertentu pengkloningan terbentuk secara alami yaitu kebiasaan proses hewan atau tumbuhan bereproduksi aseksual. Sedangkan dalam bioteknologi, kloning merujuk pada berbagai usaha yang dilakukan manusia untuk menghasilkan salinan berkas DNA atau gen, sel, atau organisme.

Telah diketahui pula bahwa makhluk hidup menggunakan DNA dan RNA untuk menyimpan dan mentransfer informasi genetiknya, karena setiap makhluk hidup menggunakan kode genetik yang sama untuk membuat proteinnya. Hal seperti inilah yang memunculkan para peneliti untuk berpikir bisa atau tidak menciptakan materi gen ini dimanipulasi sedemikian rupa agar bisa didapatkan DNA dan RNA yang sifat genetikanya sesuai dengan yang kita inginkan.

Pesatnya perkembangan teknologi rekayasa genetika haruslah terkejar oleh produk-produk fiqh yang ada selama ini. Dalam kemajuan ilmu pengetahuan, manusia telah mampu menggandakan makhluk hidup termasuk di dalamnya adalah tumbuhan, hewan, bahkan manusia belakangan ini telah berkembang satu teknologi baru yang mampu menduplikasi makhluk hidup dengan sama persis, teknologi ini di kenal dengan nama kloning.

Kloning menurut bahasa adalah berasal dari bahasa Yunani, yaitu clone atau klon yang berarti kumpulan sel turunan dari sel induk tunggal dengan reproduksi aseksual. Sedangkan menurut istilah Kloning adalah teknik membuat keturunan dengan kode genetik yang sama dengan sel induknya tanpa diawali proses pembuahan sel telur atau sperma tapi diambil dari inti sebuah sel pada makhluk hidup tertentu baik berupa tumbuhan, hewan maupun manusia. Dalam dunia kesehatan kloning juga bisa digunakan untuk menjadikan gen-gen baru yang lebih sehat dengan mengganti gen-gen rusak yang membawa kelainan dalam tubuh. Bukan hanya itu, kloning gen juga bisa dipakai untuk mengobati kelainan fisik 
dan perilaku, hidung pesek, misalnya diubah menjadi mancung. Caranya mudah, cukup dengan mengganti gen-gen yang membawa unsur pesek dengan yang mancung (Alkaf, 2003: 4)

Melihat fakta kloning manusia secara menyeluruh, syariat Islam mengharamkan kloning terhadap manusia, dengan argumentasi sebagai berikut:

1. Anak-anak produk proses kloning dihasilkan melalui cara yang tidak alami (percampuran antara sel sperma dan sel telur). Padahal, cara alami inilah yang telah ditetapkan oleh syariat sebagai sunatullah menghasilkan anak-anak dan keturunannya. Allah SWT berfirman:

"Dan bahwasannya Dialah yang menciptakan manusia berpasang-pasangan laki-laki dan perempuan dari air mani apabila dipancarkan." (QS an-Najm, 53: 45-46)

Dalam ayat lain dinyatakan pula,

"Bukankah dia dabulu setetes mani yag ditumpabkan (ke dalam rabim), kemudian mani itu menjadi segumpal darah, lalu Allah menciptakannya dan menyempumakannya. Lalu Allah menjadikan daripadanya sepasang lakilaki dan perempuan." (QS alQiyâmah, 75: 37-38).

2. Anak-anak produk kloning dari perempuan tanpa adanya laki-laki tidak akan mempunyai ayah. Anak produk kloning tersebut jika dihasilkan dari proses pemindahan sel telur yang telah digabungkan dengan inti sel tubuh ke dalam rahim perempuan yang bukan pemilik sel telur, tidak pula akan memunyai ibu sebab rahim perempuan yang menjadi tempat pemindahan sel telur tersebut hanya menjadi penampung (mediator). Oleh karena itu, kondisi ini sesungguhnya telah bertentangan dengan firman Allah SWT,

"Hai manusia, sesunggubnya kami menciptakan kamu dari seorang laki-laki dan seorang perempuan dan menjadikan kamu berbangsa-bangsa dan bersukusuku supaya kamu saling kenal-mengenal. Sesunggubnya orang yang paling mulia di antara kamu di sisi Allah ialah orang yang paling taqwa diantara kamu. Sesunggubnya Allah Maba mengetabui lagi Maha Mengenal." (QS al-Hujurât, 49:13)

Juga bertentangan dengan firman-Nya yang lain,

"Panggillah mereka (anak-anak angkat itu) dengan (memakai) nama bapakbapak mereka; Itulah yang lebih adil pada sisi Allah, dan jika kamu tidak mengetahui bapak-bapak mereka, maka (panggilah mereka sebagai) saudarasaudaramu seagama dan maula-maulamu [Maulamaula ialah: seorang bamba sabaya yang sudah dimerdekakan atau seorang yang telab dijadikan anak. angkat, seperti Salim anak angkat Huఇaifah, dipanggil maula Hu₹aifah] dan tidak ada dosa atasmu terbadap apa yang kamu kbilafpadanya, tetapi (yang ada 
dosanya) apa yang disengaja oleh hatimu. Dan adalah Allah Maha Pengampun lagi Maha Penyayang”.(QS alAhzâb. 33: 5).

Menurut Fiqih Islam kloning pada manusia dan hewan tidak terlarang dan tidak berdosa selagi menjaga tidak adanya kemudharatan pada manusia dan hewan. Kloning manusia ada yang bersifat ju₹'i; mengganti bagian tubuh yang manusia. Ada juga kloning yang bersifat kamil; membuat manusia dengan menggunakan teori seperti yang telah disebut di atas (tanpa melakukan hubungan suami istri). Qowaid Fiqbiyah menyebutkan bahwa Inti dari penjelasan kaidah ini bahwa syariat itu menjaga kemashlahatan manusia, ketika ada suatu permasalahan yaitu pertentangan antara kemashlahatan dan kemadharatan dan ternyata kemadharatannya lebih besar maka yang harus didahulukan adalah mengambil kemashlabtan. sudah tidak berfungsi dengan anggota tubuh orang lain yang sudah tidak terpakai, dengan syarat menjaga kemashlahatan.

Dalam fatwanya Majma' al-Buhûts al-Islâmiyyah menjelaskan bahwa hukum meng-kloning manusia tergantung pada cara kloning yang dilakukan. Paling tidak ada empat cara yang bisa dilakukan dalam kloning manusia:

1. Cara pertama, kloning dilakukan dengan mengambil inti sel (nucleus of cells) "wanita lain (pendonor sel telur)" yang kemudian ditanamkan ke dalam ovum wanita kandidat yang nukleusnya telah dikosongkan.

2. Cara kedua, kloning dilakukan dengan menggunakan inti sel (nucleus) "wanita kandidat" itu sendiri, dari sel telur milik sendiri bukan dari pendonor.

3. Cara ketiga, kloning dilakukan dengan menanamkan inti sel (nucleus) jantan ke dalam ovum wanita yang telah dikosongkan nukleusnya. Sel jantan ini bisa berasal dari hewan, bisa dari manusia. Terus manusia ini bisa pria lain, bisa juga suami si wanita.

4. Cara keempat, kloning dilakukan dengan cara pembuahan (fertilization) ovum oleh sperma (dengan tanpa hubungan seks) yang dengan proses tertentu bisa menghasilkan embrio-embrio kembar yang banyak.

Pada dua cara pertama, pendapat yang dikemukakan adalah haram, dilarang melakukan kloning yang semacam itu dengan dasar analogi (qiyas) kepada haramnya lesbian dan saadduzarai' (tindakan pencegahan, precaution) atas timbulnya kerancuan pada nasab atau sistem keturunan, padahal melindungi keturunan ini termasuk salah satu kewajiban agama. Di lain pihak juga akan menghancurkan sistem keluarga yang merupakan salah ajaran agama Islam. Pada cara ketiga dan keempat, kloning haram dilakukan jika sel atau sperma yang dipakai milik lelaki lain (bukan suami) atau milik hewan. Jika sel atau sperma yang dipakai milik suami sendiri 
maka hukumnya belum bisa ditentukan (tawaquf), melihat dulu maslahah dan bahayanya dalam kehidupan sosial. Untuk menentukan hukum pastinya harus didiskusikan dahulu dengan melibatkan banyak pakar dari berbagai disiplin ilmu, yang meliputi ilmuwan kedokteran, ilmuwan biologi (geneticist, biophysicist, dll), sosiolog, psikolog, ilmuwan hukum, dan agamawan (pakar fiqh).

Jika hasilnya bisa membuat kacau tatanan masyarakat (karena banyak orang kembar, sehingga jika ada tindak kriminal atau kasus hukum lainnya susah diidentifikasi, dan mungkin efek-efek lain) maka hukumnya haram. Cara mengatasinya dengan melihat maslabah dan madharatnya. Jika hukum kloning sudah menjadi keputusan haram atau halal, maka tentu bisa ditindak lanjuti melalui lembaga-lembaga yang berwenang untuk melarang atau menjatuhkan sanksi bagi para pelanggarnya.

KH. Ali Yafie dan Dr. Armahaedi Mahzar (Indonesia), Abdul Aziz Sachedina dan Imam Mohamad Mardani (AS) mengharamkan kloning, dengan alasan mengandung ancaman bagi kemanusiaan, meruntuhkan institusi perkawinan atau mengakibatkan hancurnya lembaga keluarga, merosotnya nilai manusia, menantang Tuhan, dengan bermain tuhantuhanan, kehancuran moral, budaya dan hukum.

Dari sudut agama dapat dikaitkan dengan masalah nasab yang menyangkut masalah hak waris dan pernikahan (muhrim atau bukan), bila diingat anak hasil kloning hanya mempunyai DNA dari donor nukleus saja, sehingga walaupun nukleus berasal dari suami (ayah si anak), maka DNA yang ada dalam tubuh anak tidak membawa DNA ibunya. Dia seperti bukan anak ibunya (tak ada hubungan darah, hanya sebagai anak susuan) dan persis bapaknya (haram menikah dengan saudara sepupunya, terlebih saudara sepupunya hasil kloning juga). Selain itu, menyangkut masalah kejiwaan, bila melihat bahwa beberapa kelakuan abnormal seperti kriminalitas, alkoholik dan homoseks disebabkan kelainan kromosan. Demikian pula masalah kejiwaan bagi anak-anak yang diasuh oleh single parent, barangkali akan lebih kompleks masalahnya bagi donor nukleus bukan dari suami dan yang mengandung bukan ibunya.

\section{KESIMPULAN}

Kloning menurut bahasa adalah berasal dari bahasa Yunani, yaitu clone atau klon yang berarti kumpulan sel turunan dari sel induk tunggal dengan reproduksi aseksual. Sedangkan menurut istilah Kloning adalah teknik membuat keturunan dengan kode genetik yang sama dengan sel induknya tanpa diawali proses pembuahan sel telur atau sperma tapi diambil dari inti sebuah sel pada makhluk hidup tertentu baik berupa tumbuhan, hewan maupun manusia. Dalam dunia kesehatan kloning juga 
bisa digunakan untuk menjadikan gen-gen baru yang lebih sehat dengan mengganti gen-gen rusak yang membawa kelainan dalam tubuh. Bukan hanya itu, kloning gen juga bisa dipakai untuk mengobati kelainan fisik dan perilaku, hidung pesek, misalnya diubah menjadi mancung. Caranya mudah, cukup dengan mengganti gen-gen yang membawa unsur pesek dengan yang mancung (Alkaf, 2003:4).

Melihat fakta kloning manusia secara menyeluruh, syari'at Islam mengharamkan kloning terhadap manusia, dengan argumentasi sebagai berikut: Pertama; Anak-anak produk proses kloning dihasilkan melalui cara yang tidak alami (percampuran antara sel sperma dan sel telur). Padahal, cara alami inilah yang telah ditetapkan oleh syariat sebagai sunatullah menghasilkan anak-anak dan keturunannya. Kedua; Anak-anak produk kloning dari perempuan tanpa adanya laki-laki tidak akan mempunyai ayah. Anak produk kloning tersebut jika dihasilkan dari proses pemindahan sel telur yang telah digabungkan dengan inti sel tubuh ke dalam rahim perempuan yang bukan pemilik sel telur, tidak pula akan memunyai ibu sebab rahim perempuan yang menjadi tempat pemindahan sel telur tersebut hanya menjadi penampung (mediator). Oleh karena itu, kondisi ini sesungguhnya telah bertentangan dengan firman Allah SWT.

Menurut Fiqih Islam kloning pada manusia dan hewan tidak terlarang dan tidak berdosa selagi menjaga tidak adanya kemudharatan pada manusia dan hewan. Kloning manusia ada yang bersifat ju₹'i; mengganti bagian tubuh yang manusia. Ada juga kloning yang bersifat kamil; membuat manusia dengan menggunakan teori seperti yang telah disebut di atas (tanpa melakukan hubungan suami istri). Qowaid Fiqhiyah menyebutkan bahwa Inti dari penjelasan kaidah ini bahwa syariat itu menjaga kemashlahatan manusia, ketika ada suatu permasalahan yaitu pertentangan antara kemashlabatan dan kemadharatan dan ternyata kemadharatannya lebih besar maka yang harus didahulukan adalah mengambil kemashlabtan. sudah tidak berfungsi dengan anggota tubuh orang lain yang sudah tidak terpakai, dengan syarat menjaga kemashlabatan. 


\section{DAFTAR PUSTAKA}

Ahmad Rofiq, Fiqh Mawaris, PT Raja GrafindoPersada, Jakarta, 2002.

Ahmad Rofiq, Hukum Islam di Indonesia, PT Raja Grafindo Persada, Jakarta,1995.

Alkaf, Halid, Kloning dan Bayi Tabung Masalah dan Implikasinya, Jakarta: PB UIN, 2003.

Amir Syarifuddin, Hukum Kewarisan Islam, cet. 3, Jakarta: Kencana Prenada Media Group, 2008

Isty Hafid, (Online)

http://greatminds2.wordpress.com/2010/04/17/kloning-aplikasidari-teknologi-dna-rekombinan/Muhammad Jawad Mughniyah, Fiqib Lima Mąhab, Lentera, Jakarta, 2000

Partaolan Daulay, Saleh, Kloning dalam Perspektif Islam, Jakarta: Teraju PT Mizan Media Publika 2005

R Soetojo Prawirohamidjojo, Hukum Waris Kodifikasi, Surabaya Airlangga University Press, tt.

Sayyid Sabiq, Fiqih Sunnah, Pena Pundi Aksara, Jakarta Selatan, 2006.

Tim Penulis UIN Syaif Hidayatullah, Ensiklopedi Islam Indonesia, Jakarta: Djambatan, 1992.

Yatim,Wildan, Reproduksi dan Embryologi,Bandung : Torsito 1982 